Management and leadership - a needs analysis and a training programme for leading, guiding and assessing staff in Romanian schools

Ioan Ioja, Mușata Bocoş 


\title{
Management and leadership - a needs analysis and a training programme for leading, guiding and assessing staff in Romanian schools
}

\author{
Ioan Ioja ${ }^{a^{*}}$, Mușata Bocoş ${ }^{b}$ \\ ${ }^{a}$ Doctoral School "Educational, Reflection, Development", Babeş-Bolyai University, 7 Sindicatelor Street, 400029, Cluj-Napoca, Romania \\ ${ }^{b}$ Faculty of Psychology and Educational Sciences, Babeş-Bolyai University, 7 Sindicatelor Street, 400015, Cluj-Napoca, Romania \\ *Corresponding author:ioan.ioja@gmail.com
}

\section{Abstract}

Keywords: management, leadership, the need for training in leadership competence, guiding and assessment
The new concept of the flexible, creative schools aims at diminishing the distances, the discrepancies as well as the invisible membranes which separate not only people but also schools; of course, the target is not uniforming but improving the quality of the educational act as well as of the school performance in a more and more competitive free market economy.

By starting from these aims, in 2018 we initiated a study on the training needs analysis which was the basis for the proposition of a new programme to develop leadership, management and evaluation competences, on taking into consideration the possibility and the need of a training which approaches holistically and synergetically the two dimensions of management and leadership. Considering the answers given by the teachers, we saw they gave partially correct answers to the questions regarding time management, project management, the difference between manager and leader and the functions of management.

The results of the study support the need for designing a training programme for school directors aimin at developing their competences necessary to assure a high quality management act, the increase of the degree of management performance, the improvement of educational service quality, administering of the resources, developing leadership abilities, communication and teamwork.

\section{Schlüsselworte:}

Management;

Führung/Leadership; die Notwendigkeit einer Ausbildung; Entwicklung von Führungs, Beratungund

Kontrollfähigkeiten/ kompetenzen
In dem neuen Konzept der flexiblen und kreativen Schule möchtet man die Entfernungen, Diskrepanzen und unsichtbaren Membranen verringern, die nicht nur die Menschen, sondern auch die Schulen voneinander trennen; natürlich ist das Ziel nicht die Einheitlichkeit, sondern die Steigerung der Qualität von Bildungsakt und Schulleistung im Kontext einer freien und zunehmend wettbewerbsorientierten Marktwirtschaft.

Auf der Grundlage dieser Ziele haben wir im Jahr 2018 eine Studie zur Analyse des Trainingsbedarfs gestartet, was den Vorschlag eines Programms zur Entwicklung von Führungs-, Orientierungs- und Kontrollfähigkeiten begründete und die die Möglichkeit und den Bedarf an Schulungen berücksichtigt, die sich ganzheitlich und synergistisch an die beiden Dimensionen annähert: Management und Führung/Leadership. Aus den von den Lehrern gegebenen Antworten wurde festgestellt, dass sie teilweise richtigen Antworten auf die Fragen gaben, die die Bereiche des Zeitmanagements, des Projektmanagements, der Differenzierung zwischen Manager und Leiter und Management-Funktionen abdecken.

Die Ergebnisse der Studie unterstützen den Bedarf an Schulungen und implizit die Notwendigkeit, ein Schulungsprogramm für Schulleiter zu konzipieren, das darauf abzielt, die Fähigkeiten zu entwickeln, die für die Sicherstellung eines qualifizierten Führungsakts erforderlich sind, die Leistungsfähigkeit der Führungskräfte zu steigern, die Qualität der Bildungsdienstleistungen zu erhöhen, die jeweiligen Ressourcen anzuziehen und zu verwalten und die Führungs-, Kommunikations- und Teamfähigkeit zu entwickeln.

\section{Management and leadership - two correlative concepts}

Educational Practice all over the world suggests that today leadership has surpassed management as a main descriptor when refering to leading and improving institutions in public service, being associated with change, ingenuity, motivation, inspiration and activity efficiency. From this perspective, school management should assume two simultaneous roles, apparently dichotomical: not only to automatically do what is in the position description, that is director of a public school, but also to be a leader for the human resource in that school in its totality, diversity and particularities.

The Manager-leader represents a desire of the contemporary society all over Europe, as today's world needs active social actors to participate in organisational development as well as in theoretical design and also to 
initiate and support the positive transformational force of the human resource which they not only monitor and coordinate but first of all motivate and value by offering trust, inspiring courage and the power to assume the multiple social roles responsibly. However, schools in Romania and all over the world, although considered to be flexible, perfectible systems, open to change are, in fact, controlled as regards their organisation and position by the legislation of the social and political context at a given moment. Along with the tendency of decentralization in the formal educational system, we can see the diminishing of the degree of involvement of Central political actors in planning and delivering educational services, as the distribution of authority slightly moves from top to the bottom, to the schools which belong to the national educational system.

Under these circumstances, the mission and the responsibility of delivering quality educational services is greatly assigned to school managers and their partners in the management teams, where efficient, top educational leadership and management become fundamental dimensions in order to reach the objectives and the targets set locally and regionally as well as the priorities assumed on a national level. The increase in the quality of the service delivered, keeping up with a free, competitive market, adapting to the dynamics of the rapid, profound changes on a national and European ground, make it absolutely necessary for a qualified workforce, permanently updated to the new, to diversity, to the new technologies, to the new methodological tendencies, able to face challenges, to cope with emotional stress, especially if they have management, assessment, guiding and counselling positions. Contemporary educational management requires reconfiguring and re-adapting the organisational culture, by inserting all the educational paradigms promoted worldwide, such as: education for all, education from all life experience, permanent education, lifelong learning, sustainable development, etc. Without incorporating the dimension of leadership, educational management can no longer reach the results in terms of performance and success in a world in which educational standards have been much raised and the beneficiaries' expectations are also very high.

The European documents such as the strategy Europe 2020 of the European Commission focus on education, the school plays an essential role not only in training and developing the workforce but also in assuring its access and insertion all of the work market; this way it is obvious the fact that there are ever greater expectations from the contemporary school and educational managers have to assume responsibility aiming at human development in all its complexity. A new pattern of life, where Society is a huge living organism and all its elements are connected and interdependent, new values and holistic strategies appear, focusing on learning and preparing for survival, innovation, creativity, involvement, network communication, valuing diversity and integrating it, etc. Forming and developing life and professional competence are not possible without triggering factors, without challenging learning contexts, without people involved, engaged and motivated to look beyond the dimension of the immediate future and of a knowledgeable existential comfort.

The national documents such as the Law of the National Education (http://oldsite.edu.ro/index.php/articles/14847) and The Regulations for organising and functioning of schools (https://www.edu.ro/etichete/rofuip) address the same needs and tendencies presented above, the leader manager being today a key actor of the formal education system in Romania. Educational Practice at the bottom of the pyramid in urban and rural schools in Romania still highlights the fact that many times the school manager is not the school leader as well. This kind of situations explain the performance discrepancies among schools the discrepancies of approaching the problems contemporary School has to cope with the discrepancies of the learning and teaching strategies teachers apply in class, the differences of the way they communicate, relate with and integrate in the regional and local community, the way they use the existing teaching materials... In a nutshell, we could say that management without leadership just meet the opportunities while management and leadership me too the opportunities and use them.

\section{Needs analysis regarding management and leadership in Bistrița-Năsăud County}

Participation and involvement in the activities people do on a daily basis, including those from their workplace, we present a vital dimension for the human being for they are personal and professional development, because this way they develop competences and acquire new ones, they communicate and relate with other people, and moreover, they give a meaning, a direction to their own life, engaging and connecting to the others (Law, 2002).

Participation/ involvement represents an indicator of the competence and the quality of the action achieved by a person at a given moment, an indicator of a person's ability 
to look beyond oneself and the responsibility for their own self as a dimension of belonging; The personal goal is achieved by PARTICIPATING to the goal of the group, of the whole. Participation does not mean only ACTION but rather ENGAGEMENT, RESPONSIBILITY, INNER INVOLVEMENT (of the soul, mental and moral), elements which are not always visible from the outside and not very easy to measure, but which can influence actions in decisive way (Vlașin, 2013).

The Human resource in an institution should and can be engaged in a creative act as co-authors, co-designers and co-participants in a collective effort for development, for sustainable yet flexible, open to change design. Quality professionalisation is favoured by interdisciplinary teamwork allowing the burst of ideas, their overflowing and the strengthening of individual communication competence in a diverse environment which becomes even stronger when the members of the teams change often.

Managing a school implies fulfilling creatively, flexibly and coherently a system of management traits: analysis, identification and documentation on the alternatives, choosing the alternatives (management option), planning, organising and guiding, monitoring, checking, assessing, feedback (Bocoș, (coord.), 2015).

By starting from these ends, in 2018 I initiated a study regarding training needs analysis in order to develop management, guiding and assessment competences. The training program designed regarding the possibility and the need overtraining approaching holistically and synergetically the two dimensions: management and leadership in such a way that most schools in BistriţaNăsăud county to have leader-managers in order to diminish the distances, the discrepancies and the invisible membranes which separate not only people but also schools. Our target is not equalising them but the increase of the quality of the educational performance as well as the school performance in a more and more competitive free market economy. The directors, the administrative staff are vital mediators of change regarding the teachers before, while and after periods of intense work. It is important for the members of the management team to be aware of the part they can play in minimising or maximising the level of stress of teachers and staff and to offer them opportunities to develop there management abilities for them to function as well as possible during times of change.

In order to identify and document the need for training, which we initially supposed through the analysis of the main European and national law document we mentioned before, through the analysis of some general inspection or focused inspection reports done by Inspectoratul Școlar Județean Bistriţa-Năsăud along the last two school years and also through talks with school inspectors monitoring educational management activity in the County, we made and applied two questionnaires as follows:

First, in order to identify and study the training needs in "Management and Leadership in education", we applied a questionnaire to directors / deputy directors / members of the Board of Administration/ members of the Commission for quality assurance and evaluation in schools of BistrițaNăsăud county. 278 teachers answered these questionnaires, 211 female teachers $(75,9 \%)$ and 67 male teachers $(24,1 \%), 148$ of them working in rural schools $(53,24 \%)$ and 130 in urban schools $(46,76 \%)$. As to their age, 10 are under $30(3,6 \%), 69$ are between 30 and 40 $(24,82 \%), 119$ between 40 and $50(42,8 \%)$, while 80 are over $50(28,78 \%)$. The teachers who answered the questionnaires belong to schools with different structures.

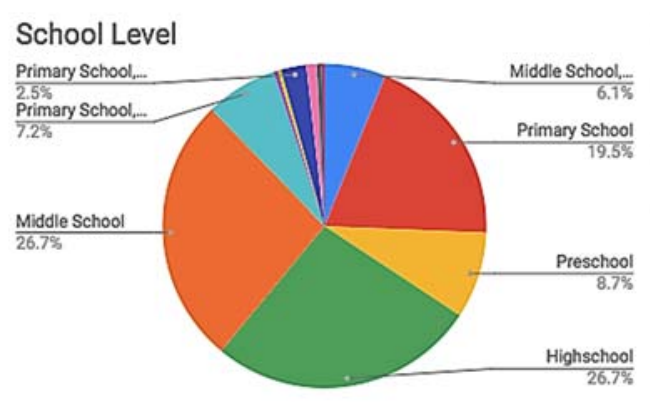

Figure no. 1. Biological gender

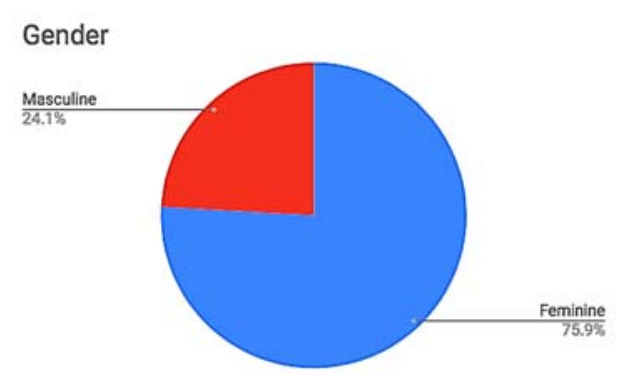

Figure no. 2. Education levels 
The questionnaire was made by considering the management roles of a director (Barry, 1991) namely:

Visionary: This type of management can be defined through creating and aggregating new versions inside the group. When solving a problem, visionary leaders have the ability to provide numerous solutions, but only some of them can be accepted by the others. Because they usually have visions different from the rest of the group, they can encounter problems of functioning inside the group, so they prefer to invent and create separately. Such persons will try to introduce their ideas inside the group only after the group has already engaged in certain actions.

Organiser: This type of management has the role to make order in the discussions taking place inside the group. The behaviour and characteristics of this type of management are: focus on details, time limits, time, efficiency and structure. Such people are usually preocupa to make things as clear as possible and to achieve the tasks without wasting time.

Relator: This type of management supposes preoccupation to maintain relationships with the exterior, to create and maintain a strong image of the team. This leader is usually focused on his or her own self, following his own interests and even sabotage the group to the extreme. He can be productive when he identifies with the needs of the group when his aims match the aims of the group.

Social: the social leader is that person who is mainly preoccupied with developing and maintaining the team

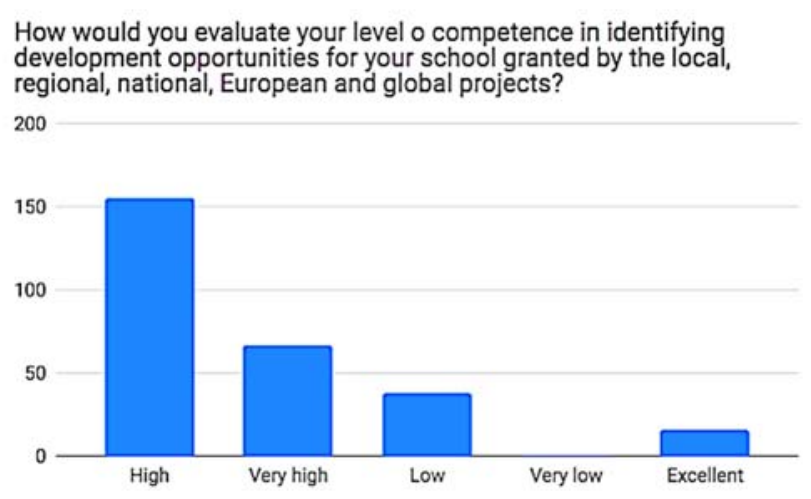

Figure no. 3. The level of competence regarding strategic planning of the activity in a school institution from a psychological perspective. The general characteristics include identifying the needs and preoccupations of the different group members, ensuring that each group member speaks his or her opinion, matching with the level of energy and emotional state of the group, introducing humour and welfare in the group, and having the ability to mediate conflicts. The efficiency of this type of management can be seen when the group works hard, encouraged by the members of the team. This type of management requires constant attention and activity.

The training needs analysis for directors regarded 6 key fields of school management:

- Strategic management design

- Implementing a management strategy

- Designing an e-safety plan of action

- Knowing the employees needs and rights

- Identifying the institutional development opportunities through projects

- Writing and implementing projects.

The interpretation of data revealed that the level of appreciation good is predominant in both categories, urban schools and rural schools, the differences between the two categories being insignificant. Likewise, the appreciations WEAK or even UNSATISFACTORY are obviously predominant to the respondents working in rural schools for 6 dependent variables, except for the variable: Knowing the employees needs and rights, where the answers do not differ.

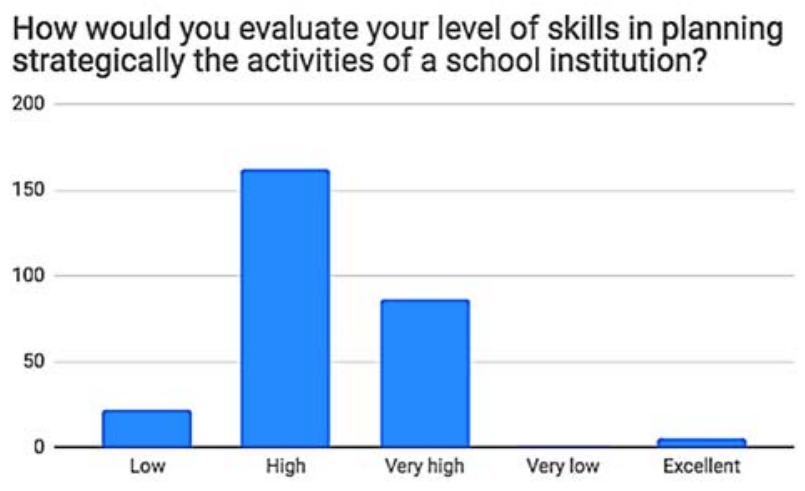

Figure no. 4. The level of competence in implementing a management strategy in a school institution

It is interesting to notice that the level of competence regarding strategic design of the activity of a school institution and the implementation of such a strategy is appreciated by $70 \%$ of the respondents as good, very good or excellent. 
However, when it comes to writing and implementing a project externally funded, things change as $70 \%$ think they do not have such competence developed.

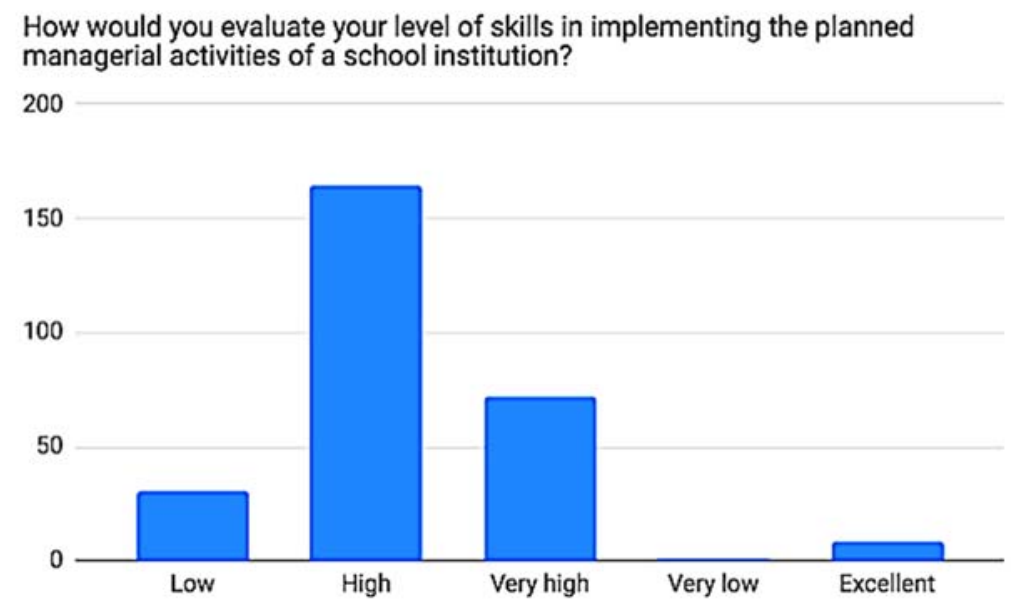

Figure no. 5. The level of competence in identifying development opportunities through local, regional, national, European and international projects

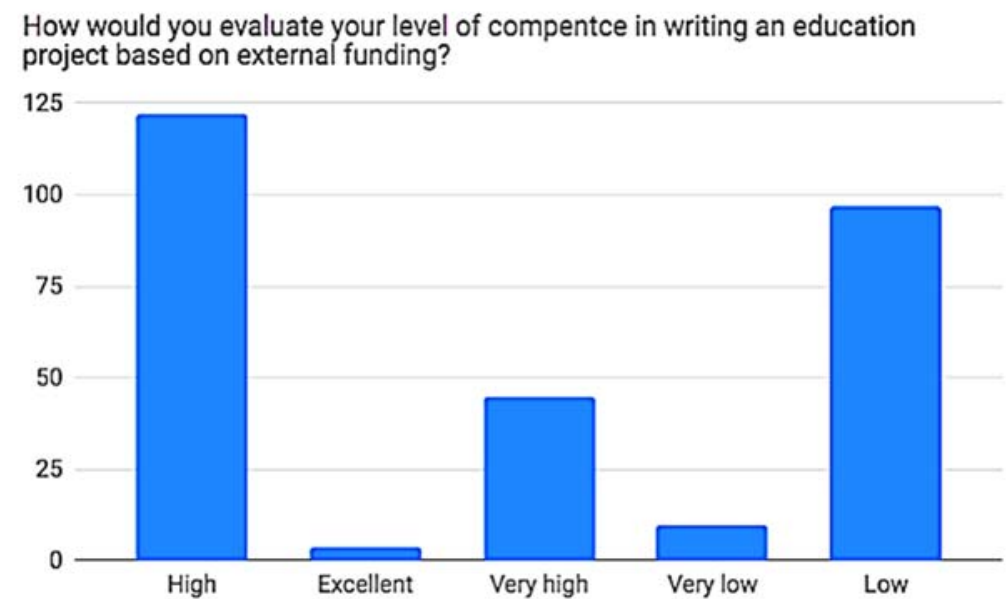

Figure no. 6. The level of competence in writing an externally funded educational project

The data presented support the fact that we need to consolidate/ develop the competences needed in the educational management and leadership process, including the teachers who occupy leading, guiding and assessment positions in school institutions, which would lead to an increase in the quality of the management act, to its adaptation to the dynamics, tendencies and expectations of a performant European educational management, to the increase of the prestige of the Romanian school on an international level.
The need for training in this direction seems to be more imperative in the case of the educational actors from rural school institutions, as the effort to diminish the discrepancy as to school performance between rural and urban school institutions is necessary to suppose the training of human resources, employees of the national educational system, regarding their professional and personal development, the increase of the level of satisfaction and quality of life in their workplace.

The second stage of identifying the training needs meant the creation of a second self assessment 
questionnaire with 10 questions of medium difficulty in order to check the knowledge of educational leadership and management. This was applied to a number of 110 teachers who are directors or deputy directors in school institutions. By accepting the idea that "acquiring some competence supposes, as a decisive landmark, action, that is taking a set of steps: using adequate resources in different situations (educational, social, professional, life situations), checking the relevance of these resources, using them efficiently, approaching the situation, checking the validity of the result" (Bocoss, (coord.), 2015). The assessment questionnaire was intended to allow the identification of those types of competences, knowledge, abilities and attitudes which can be developed through training courses intended to support school directors activity. The 10 questions helped to point out the strengths of the management activity, the domains where possible improvements are necessary or desired, the priorities as to planning professional development activities of the staff and the quality standards of the school activity have been appreciated.

This time as well the greatest difficulties, that is partially correct answers, have been recorded at the questions regarding time management, project management, the differences between manager and leader, the functions of management.

\section{Conclusions}

The data collected by applying the two questionnaires and their statistical analysis support the need for training, the need to develop management, guiding and assessment competence necessary to assure quality management acts, the improvement of management performance, the improvement of Educational service quality, the alignment of school institutions in Romania to the European and International quality standards in order to acquire the mobility of Educational actors, to create international, European and national educational cooperation networks.

In conclusion by designing a training program for school directors we intend to develop they are combat of designing a strategy to develop the educational institutions, to implement and manage the strategic changes in the organisation, to manage the resources in order to develop leadership abilities, communication and teamwork.

\section{Authors note:}

Ioan Ioja is currently a teacher at Colegiul Tehnic Infoel Bistrița, BN, Romania, and Doctoral Student at BabeșBolyai University, director of Teachers' Training Institution of Bistrița-Năsăud county. His research areas are aimed at providing meaningful initial and lifelong training for teachers and at an efficient insertion of young graduates in schools. He is also interested in finding the teachers' learning needs in order to meet their expectations and offer them appropriate training programmes.

Muşata Bocoş is University Professor and Ph.D. Coordinator at the Faculty of Psychology and Sciences of Education (Babeș-Bolyai University, Cluj-Napoca, Romania). She has obtained a Ph.D. in Educational Sciences in 1997 at Babeș-Bolyai University. Her research interests are reflected in a series of studies and articles published in important national and international journals. Her teaching activity covers several domains such as the theory and methodology of curriculum, general didactics, and educational research.

\section{References}

Barry, D. (1991). Managing the bossless team: Lessons in distributed leadership. Organizational Dynamics, 20, 31-47.

Bocoş, M.-D. (coord.), Răduţ-Taciu, R., Stan, C., Chiș, O., Andronache, D. (2015). Dictionar praxiologic de pedagogie. Volumul I: $A-D$. Piteşti: Paralela 45 Publishing House.

Law, M. (2002). Participation in the Occupations of Everyday Life, The American Journal of Occupational Therapy. Volume 56, Number 6.

Vlașin, I. (2013). Competența. Participarea de calitate la indemâna oricui. Alba Iulia: Editura Unirea.

*http://oldsite.edu.ro/index.php/articles/14847.

*https://www.edu.ro/etichete/rofuip. 